\title{
FOOD INSECURITY AND NUTRITIONAL STATUS AMONG WOMEN IN PALM-PLANTATION AREA OF KUTAI KERTANEGARA EAST KALIMANTAN
}

\author{
Annisa Nurrachmawati ${ }^{1}$, Ike Anggraeni ${ }^{1}$, Riza Hayati Ifroh ${ }^{2}$, Reny Noviasty ${ }^{3}$ \\ ${ }^{1}$ Departement of Biostatistics and Health Reproduction, Mulawarman University, Samarinda \\ ${ }^{2}$ Department of Health Promotion, Faculty of Public Health, Mulawarman University, Samarinda \\ ${ }^{3}$ Department of Nutrition, Faculty of Public Health, Mulawarman University, Samarinda
}

\begin{abstract}
The inability of individuals and households to providing adequate, nutritious, and safe food will continue in conditions of food insecurity, which have an impact on malnutrition. Women play an important role in maintaining household food security while they are also vulnerable to food insecurity. This study aims to examine the correlation between food insecurity and women's nutritional status. The study design was a cross-sectional study, with a sample consist of 128 women in reproductive age who lived in palm plantation area in Kutai Kertanegara. The sampling technique was purposive. Food insecurity was assessed by the Radimer/Cornell Hunger and Food Insecurity Instrument Questionnaire. The nutritional status of women measured by Body Mass Index and upper arm circumference. Bivariate analysis was performed by Chi-Square test. Household food insecurity was reported in $27.3 \%$ women, individual food insecurity was found in $29.7 \%$ women, and $8.6 \%$ child hunger. Bivariate analysis showed there is no significant correlation between food insecurity with nutritional status based on BMI or upper arm circumference. It should be made a comprehensive public health nutrition program to address food insecurity in a remote areas. Future studies would need adequate study design and larger sample size to examine women nutritional status and food insecurity.
\end{abstract}

Keywords : Food Insecurity, Nutritional Status, Palm-Plantation

\section{KERAWANAN PANGAN DAN STATUS GIZI PEREMPUAN YANG MENETAP DI AREA PERKEBUNAN KELAPA SAWIT DI KABUPATEN KUTAI KERTANEGARA KALIMANTAN TIMUR}

\begin{abstract}
ABSTRAK
Ketidakmampuan individu dan rumah tangga dalam menyediakan makanan yang memadai, bergizi dan aman merupakan faktor risiko kondisi kerawanan pangan, yang berdampak pada masalah status gizi. Perempuan memainkan peran penting dalam menjaga ketahanan pangan rumah tangga sementara mereka sendiri juga rentan terhadap kerawanan pangan. Penelitian ini bertujuan untuk menguji hubungan antara kerawanan pangan dan status gizi wanita. Desain penelitian cross sectional, dengan sampel sejumlah 128 wanita usia reproduksi yang tinggal di daerah perkebunan kelapa sawit di Kutai Kertanegara. Teknik pengambilan sampel adalah purposif. Kerawanan pangan dinilai dengan kuesioner dari Radimer/Cornell Hunger dan Food Insecurity Instrument. Status gizi wanita diukur dengan Indeks Massa Tubuh dan lingkar lengan atas. Analisis Bivariat dilakukan dengan uji Chi Square. Keamanan pangan rumah tangga dilaporkan pada 27,3\% wanita, kerawanan pangan individu ditemukan pada $29,7 \%$ wanita, dan 8,6\% mengalami kelaparan anak. Analisis bivariat menunjukkan tidak ada korelasi yang signifikan antara ketahanan pangan dengan status gizi berdasarkan BMI atau lingkar lengan atas. Harus ada program gizi kesehatan masyarakat yang komprehensif untuk mengatasi kerawanan pangan di daerah pedesaan. Studi di masa depan akan membutuhkan desain
\end{abstract}

\footnotetext{
1 Correspondece Address: Annisa Nurrachmawati Faculty of Public Health, Mulawarman University, Samarinda Jl.Sambaliung Kampus Unmul Gunung Kelua Samarinda Email: nasywa_mzi@yahoo.com
} 
penelitian yang lebih adekuat dan ukuran sampel yang lebih besar untuk menentukan korelasi antara status gizi wanita dan kerawanan pangan.

Kata Kunci: Kerawanan pangan, status gizi, perkebunan sawit

\section{INTRODUCTION}

Fulfillment of households food needs for as reflected by the availability of sufficient food in terms of quantity and quality, safe, equitable and affordable and not contradictory to the religion, beliefs, and culture of the community, to be able to live healthy, active and productive sustainably which the component contained in the Food Security Law No. 18 in 2012. Based on the policy, each community was entitled to access to food from economic, social, cultural as to avoid food insecurity.

The Indonesian Food Security Agency has established a food security index based on 3 aspects namely access to food availability, access to food affordability and access to food use with a cut-off point, which is the area included in group 1 (value $\leq 41.52$ to rural area and $\leq 28.84$ to urban area) was an area that tends to have a higher level of vulnerability than rural or urban with a group above, conversely regions in group 6 with values> 75.68 and $>70.64$ respectively for districts and cities that have the most food security well. The conclusions of Kalimantan, food security status, was categorized as good. ${ }^{1}$ However, there were still areas with low access to food availability and food affordability, namely oil palm plantations. This area was at risk for food insecurity due to a considerable distance from the capital as a source of food suppliers, as well as difficult access, and located far from residential areas. This is compounded by the lack of land to be able to grow their own food as a result of deforestation. Some studies in agriculture such as palm plantation, showed similar conditions, which large-scale industrial crop expansion had influenced local food security and rural livelihoods. ${ }^{2,3}$

Oil palm plantation area which continues to grow rapidly becoming a commodity in East Kalimantan. The total area of oil palm was growing fast, and now, in 2016, it reached $1,150,078 .{ }^{4}$ These indicated that the sector was essential for the region as a source of supply of raw materials for energy and shore up the economy. This growth has a positive impact on the economy. However its adverse effects cannot be ignored. Oil palm plantations are associated with forms of investment and land acquisition, and seizure of small-scale farmers and local communities, which indicates broad implications for welfare and justice. ${ }^{5}$ One of the impacts on public health is food insecurity. Food security and healthy nutrition status are necessary for human's growth and development. Growth and development needed access to sufficient, various, and high-quality food resources. Given their contribution to providing food both for themselves and their families, their role in society as child-bearers and caregivers, and their poor economic status the role of women is very important. ${ }^{6}$

Women are the deciding actors in achieving food security at the household, individual level, and for their children. Activities in meeting food needs begin with food crop cultivation, food procurement, collection and exchange, food preparation and processing until food distribution is dominated by the role of women in the household. ${ }^{7}$ Women in palm plantation face the double burden of domestic affairs and work. The majority of women in oil palm plantations are oil palm plantation workers, some of them were the breadwinner of the family. Majority women worker status were casual laborers means they were outsourcing both officially and unofficially. These conditions put women at risk because women casual laborers receive lower wages, compare to man, they also work 
without adequate safety, and health protection. $^{8}$ Another risk they face is malnutrition. Data FAO, and WHO in 2014 showed majority of farm households are affected by undernutrition and micronutrient malnutrition. ${ }^{9}$ Based on that, this study's purpose was to find out the correlation between food insecurity and women's nutritional status in the palm plantation area.

\section{METHOD}

The cross-sectional study of women around palm oil plantation was conducted in Saliki village, a rural area in Kutai Kertanegara Regency, East Kalimantan. As much as 128 women become samples in this study. The sample size calculated used the hypothesis testing of two different proportions. ${ }^{10}$ Purposively divine by inclusion criteria; nonpregnant, nonlactating and healthy women.

Food insecurity was assessed by the Radimer/ Cornell Hunger and Food Insecurity Instrument Questionnaire. According to this instrumet food, insecurity is measured in eight concepts at the individual and household level in 10 question items. The food insecurity concepts at the individual level are (a) insufficient intake, (b) nutritional inadequacy, (c) lack of choice and feeling of deprivation, and (d) disrupted eating pattern. At the household level, these are: (e) food depletion, (f) unsuitable food, (g) food anxiety, and (h) food acquisition in a socially acceptable way.

The categorization namely; food secure if negative answer to all ten questions, household food insecure if response positive answer (sometimes correct or often correct) to one or more of questions no.1-4, individual food insecure: positive answer to one or more of question no 5-8, child hunger: positive answer to items $9-10 .{ }^{11}$ This instrument has been applied in a few studies in Indonesia setting. ${ }^{12,13}$
The dietary habit was measured using Food Frequency Questioner. ${ }^{14}$ The nutritional status of women living in the area of palm oil plantation measured by the anthropometric index, consists of Body Mass Index (BMI) to assess the proportion of body weight to height and upper arm circumference to assess the risk of chronic energy deficiency. Body weight measured by calibrated digital weight scales and height measured by stature meter. BMI categorization refers to BMI scores based on the Indonesia Ministry of Health a classification (2019) namely: thin <18.5, normal 18.5-25, and fat $>25 .{ }^{15}$ Measurement of upper arm using upper arm circumference tape with classification of upper arm circumference $<23.5 \mathrm{~cm}$ at risk of chronic energy deficiency and $\geq 23.5 \mathrm{~cm}$ have no risk of chronic energy deficiency. ${ }^{16}$ An analysis between food insecurity and nutritional status was performed by Chi-Square test.

Permissions to enter the palm plantation area was obtained. Respondents had given information about the aim of the study, and we assuring them about their confidentiality. The study was approved by the Research Ethics Committee at Ethics Committee Faculty of Medicine, Mulawarman University , No.87/KEPK-FK/VI/2019.

\section{RESULT}

This study showed the majority of the respondent (93.8\%) lived in a household with mean of monthly income was 4.519.140 IDR. This household income is above Provincial Minimum Wage 2019, which 2.747.560 IDR. Nevertheless household expenditure on food is low. The majority of food expenditure (82.0\%) is below $60 \%$. The average expenditure for food is categorized well if it reached $60 \%$ compared to income. It would indicate that food consumption expenditure still dominates household expenditure. The complete characteristic is presented in table 1 . 
Table 1. Distribution of Respondents Characteristic

\begin{tabular}{lcc}
\hline \multicolumn{1}{c}{ Variable } & N & $(\boldsymbol{\%})$ \\
\hline $\begin{array}{l}\text { Household Income } \\
\text { < Provincial Minimum Wage }\end{array}$ & 8 & 6.3 \\
Z Provincial Minimum Wage & 120 & 93.8 \\
The Proportion of Food Expenditure & & \\
$\leq 60 \%$ & 105 & 82 \\
$>60 \%$ & 23 & 18 \\
Food Security Status & & \\
Food Secure & 43 & 34.4 \\
Household Food Insecurity & 35 & 27.3 \\
Individual Food Insecurity & 38 & 29.7 \\
Child Hunger & 11 & 8.6 \\
\hline
\end{tabular}

Table 1 also presented about the distribution of respondents based on food security status. It could be concluded that the majority of respondents $(65.6 \%)$ were in the status of food insecurity, which households with individual food insecurity status constitute the highest proportion among the three food insecurity categories. Although the percentage is low, but there have been child hunger (8.6\%).

\section{Table 2. Distribution of Respondents Statement on Radimer/Cornell Hunger and Food Insecurity Items}

\begin{tabular}{lc}
\hline \multicolumn{1}{c}{ Statements } & Frequency (\%) \\
\hline I worry whether my food will run out before I get money to buy more & $62(48,4)$ \\
The food that I bought just didn't last and I didn't have money to get more & $4(3,1)$ \\
I ran out of foods that I needed to put together a meal and I didn't have & $32(25)$ \\
money to get more food & \\
We eat the same thing for several days in a row because we only have a & \\
few different kinds of food at hand and we didn't have money to buy more & $43(33,6)$ \\
I can't afford to eat properly & $38(29,7)$ \\
I am often hungry but I don't eat because I can't afford enough food & $13(10,2)$ \\
I eat less than I I should because I don't have enough money for food & $18(14,1)$ \\
I can't give my children a balanced meal because I can't afford that & $19(14,8)$ \\
My children is/are not eating enough because I just can't afford enough & $10(7,8)$ \\
food & $4(3,1)$ \\
I know my children is/are hungry sometimes, but I just can't afford more & \\
food &
\end{tabular}

Based on data presented in table 2, it could be concluded most respondents worried they run out of food before earning the next month's income $(43 \%)$. The coping strategy that they had done was eating the same things in a row several times $(33.6 \%)$.

The results of the Food Frequency Questionnaire (FFQ) scoring showed that the most staple food source consumed by the respondents was rice (mean score 48.82), the frequency of eating $>1$ time per day. The most protein source comes from fresh fish (mean score 33.76 ) with a frequency of eating $>1 \mathrm{x}$ per day then obtained from chicken eggs (mean score 23.75). Other sources of protein were from soy, namely tempeh (mean score 18.58), and tofu (mean score 18.20). Fulfillment of vitamins and minerals obtained from the consumption of vegetables and fruit. The most dominant green vegetables consumed is spinach with a mean score of 17.48 , which is consumed 4-6 times per week, for other vegetables that are consumed a lot is tomatoes with a mean score of 29.89 consumed $>1 \mathrm{x}$ per day. 
The most consumed fruit is papaya (mean score 7.57 ) with a frequency of 2-3 times per week. Fulfillment of micronutrients such as calcium, phosphorus, zinc obtained from the consumption of milk and its products, which mostly come from sweetened condensed milk (mean score 9.25) with a frequency of 1 time per day. It is also known that fast food consumes the most instant noodles (mean score 14.85) with a frequency of 2-3 times per week. Beverages mostly consumed was tea (mean score 21.6) once a day, we also found beverages which contain high levels of sugar or artificial sweeteners such as syrup (mean score 6.46) and soda (mean score 2.6) are consumed in 2-3 times per week

Table 3. Women Nutritional Status based on Body Mass Index and Upper Arm Circumference

\begin{tabular}{lcc}
\hline Variable & N & $(\%)$ \\
\hline Body Mass Index & & \\
Underweight & 4 & 3.1 \\
Normal & 69 & 53.9 \\
Overweight & 55 & 43.0 \\
Upper Arm Circumference & & \\
$\geq 23,5 \mathrm{~cm}$ & 122 & 95.3 \\
$<23,5 \mathrm{~cm}$ & 6 & 4.7 \\
\hline
\end{tabular}

Nutritional status indicates the use of nutrients by the body that is represented in physical body condition or the ability of the functions of the body's organs. Data in Table 3 showed that $46.1 \%$ had malnutrition, namely
$3.1 \%$ underweight, and majority had overweight $(43 \%)$. Meanwhile, the measurement of upper arm circumference showed that most women had a normal conditions $(95.3 \%)$.

Table 4. Correlation of Women Nutritional Status with Food Insecurity

\begin{tabular}{lcccc}
\hline \multicolumn{1}{c}{ Variable } & Food Insecurity & Food Secure & Total & P-Value \\
& $\mathrm{N} \%$ & $\mathrm{~N}(\%)$ & $\mathrm{N}(\%)$ & \\
\hline Body Mass Index & & & & \\
Underweight & $2(50)$ & $2(50)$ & $4(100)$ & 0.485 \\
Normal & $43(62.3)$ & $26(37.7)$ & $69(100)$ & \\
Overweight & $39(70.9)$ & $16(29.1)$ & $55(100)$ & \\
Upper Arm Circumference & & & & \\
$\geq 23,5 \mathrm{~cm}$ & $82(67.2)$ & $40(32.8)$ & $6(100)$ & 0.088 \\
$<23,5 \mathrm{~cm}$ & $2(33.3)$ & $4(66.7)$ & $6(100)$ & \\
\hline
\end{tabular}

Analysis Bivariate showed that there was no correlation between women's

\section{DISCUSSION}

This study showed that of the $65.6 \%$ of respondents categorized as food insecurity, among them $27.3 \%$ had household food insecurity, $29.7 \%$ categorized as individual food insecurity, and $8.6 \%$ categorized had children's hunger. The study of Zalihah and Tham stated that among all the Sawit worker households in Hulu Langat Selangor, Malaysia food insecurity also happened. ${ }^{17}$ The nutritional status based on BMI as well as with upper arm circumference with food insecurity.

highest was individual food insecurity $(32.8 \%)$, in which native inhabitants were the most vulnerable group compare to the household of the migrant workers.

Individual food insecurity, especially in women, was related to the mother sacrifices to meet the consumption and nutritional needs of their children and husbands. That household couldn't buy enough food because of a lack of 
money, so they have to put their husbands and children first. ${ }^{18}$ According to Quisimbing and Malucio, several studies had shown when compared to men, women who play a role in controlling assets and household resources tend to use their income for household needs, especially to meet the needs of children. ${ }^{19}$

The results of this study showed there were $8.6 \%$ repondents who stated that children's hunger happened in their household. Based on respondents' answers on the qualitative component of the Radimer/ Cornell instrument, $14.8 \%$ of respondents stated their inability to provide healthy, nutritious, and balanced food for children. According to Naser, total monthly income and food expenditure were significant risk factors for household food insecurity. ${ }^{20}$ Food insecurity, which happened in the childhood period, would affect children health status in the future. Among children, household food insecurity was associated with being stunting in urban city Indonesia. ${ }^{21}$ It also affects intelligence and mental health, the study of Belsky showed that food-insecure children had lower IQs and higher levels of behavioral and emotional problems relative to their peers. ${ }^{22}$

Food insecurity in household level, individual level, and children hunger have correlated with household income. Limited income causes a household only afford to buy lower quality and quantity of food, which results in food insecurity. ${ }^{23}$ Ironic condition because most respondents' income (93.8\%) is above the provincial minimum wage. This ironic condition could be explained in accordance with the theory of consumer behavior in Engel's Law, which stated that at the time of an increase in income, consumers would spend their income on food with a low percentage, on the contrary if income decreases, the percentage spent on food increased. ${ }^{24}$

The other explanation was about sufficient access of food supply. The distance between the capital city of Samarinda with the area of oil palm plantations reaches $36 \mathrm{~km}$ and can be reached within 1 hour 50 minutes, while the nearest food access comes from the town of Muara Badak District which is about $17.9 \mathrm{~km}$ and takes 36 minutes to reach the palm oil plantation area with the terrain is quite difficult. This all geographical difficulties caused increase the food price, and become an obstacle for household to afford sufficient quality and quantity of food they needed.

This condition is in line with research by Mohamadpour which showed that food insecurity also happened in palm plantation households in Malaysia, which the conditions of households residing in palm plantations could also affect food availability and accessibility because households have limited access to markets, lack of land for subsistence agriculture and payments, and higher food costs. $^{25}$

Anthropometric measurements that have been carried out on respodents showed that the majority $(43.0 \%)$ of respondents categorized as overweight while the upper arm circumference measurement also showed results consistent with BMI. Majority of respondents $(95.3 \%)$ were not at risk of chronic energy deficiency. Overweight and obesity occurred not only induced by over sufficient in quantity or quality food, but rather reflected of the condition of an unbalanced portion and minimal food diversity, mainly from only one or two high calories of food sources.

Previous research in the area of oil palm plantations in Malaysia also showed a similar condition, where there were 95 (64.6\%) respondents categorized as overweight. ${ }^{25}$ Study of Shariff in the Sabak Regency area of Selangor City Malaysia covering 12 villages and two oil palm plantations. This region is located in $150 \mathrm{~km}$ from the capital city of Kuala Lumpur. The study showed more than $50 \%$ of women in each food insecurity group were obese and overweight. Some other research results 
showed a correlation between food insecurity with overweight or obesity. Study of Yunieswati $^{26}$ informed correlation between nutritional status and central obesity in the incidence of farmers illness.

The results of research on Brazilian women in urban areas showed that there were $73 \%$ of respondents who experienced food insecurity and found an association between moderate food insecurity with obesity. ${ }^{27}$ Likewise, obtained from the results of research on women in Kenya, which found a positive association between food insecurity with the incidence of obesity and obesity. ${ }^{28}$ Although the instruments used were different, specifically using the Household Food Insecurity Access Scale (HFIAS) by FAO, but it has similarities with Radimer/Cornell that explored the conditions of food security. ${ }^{29}$

Food insecurity caused not merely insufficient food needs in terms of quantity, but also in terms of food diversity, nutrients, and safety of the food, both at the household, individual, and children, that explains food insecurity could cause overweight/obesity. Although this study did not measure the number of servings consumed at the household or individual level, the food frequency questionnaire is used to explore the diversity of food consumed and the unavailability of food at the household or individual level. Our study showed that processed foods, namely instant noodles (mean score 14.85) are the most consumed types of fast food. Consumption of instant noodles in Indonesia reaches 75 packs / capita / year. Data from Riskesdas 2013 also showed that 6 out of 10 people in Indonesia consume instant noodles more than once a day. The high frquency of instant noodle consuming certainly have a major effect on nutritional status. Instant noodles are considered as unhealthy food or as a type of junk food. A single serving of instant noodles is usually high in carbohydrates but low in fiber, vitamins, and minerals. Studies in Korea showed consuming instant noodles could cause an excessive intake of energy, fat, and sodium. ${ }^{30}$

Our study also found beverages that contain high levels of sugar or artificial sweeteners such as syrup ( mean score 6.46) and soda (mean score 2.6) are consumed a lot per day. Metaanalysis from Ruanpeng stated that relative risk for obesity was higher among patients consuming either sugar or artificially sweetened soda compare to those who did not. ${ }^{31}$ Systematic reviews from Farrel provides an initial framework to understand the link between food insecurity and overweight. The main mechanism was the consumption of processed foods. ${ }^{28}$ Processed foods and drinks are generally energy-dense but low in micronutrients. Low energy micronutrient-dense foods, commonly referred to as Energy-Dense, Nutrient Poor Foods (EDNP) are categorized into visible fats, sweeteners, dessert, salty snacks. The health risks from processed foods were the high levels of saturated fat, trans fat, cholesterol, carbohydrate, sugar and, sodium. Advance problems were low levels of fiber and micronutrients such as vitamins $\mathrm{A}, \mathrm{C}, \mathrm{E}$, B6, B12 and E, folate, iron and, calcium. Even though WHO has recommended reducing salt intake $<5$ grams per day, sugar $<10 \%$ and, fat $<30 \%$ of total energy requirements per day. Excessive consumption of these foods could lead to overweight triggering the risk of non-communicable diseases. ${ }^{32}$

\section{CONCLUSION}

The majority of women have a normal BMI (53.9\%), and normal upper arm circumference (95.3\%). Nevertheless, this study could not find the significant correlation between food insecurity with nutritional status based on BMI or upper arm circumference, but this study delivered that household food insecurity (27.3\%) could occur in the family who have a household income above Provincial Minimum Wage. Another finding 
was identified women who are categorized as overweight in food insecurity households. These results should raise awareness that food insecurity is not merely could be associated with poverty and undernutrition but also within households with sufficient income, and obesity. There must be a comprehensive

\section{REFERENCES}

1. Tangerang City Research and Development Center. Indonesian Food Security Index. Jakarta: Ministry of Agriculture's Food Security Agency; 2018.

2. International Fund For Agricultural Development (IFAD). Smallholders, food security, and the environment. France: United Nations Environment Programme; 2013.

3. Balde BS, Diawara M, Rossignoli CM, Gasparatos A. Smallholder-based oil palm and rubber production in the forest region of guinea: An exploratory analysis of household food security outcomes. Agric. 2019;9(2):1-19.

4. Statistics East Kalimantan. East Kalimantan Province in Figures 2018. Statistics Integration Processing and Dissemination, editor. BPS. Jakarta: BPS Provinsi Kalimantan Timur; 2018.

5. Elmhirst R, Siscawati M, Basnett BS. Navigating Investment and Dispossession: Gendered Impacts of the Oil Palm "Land Rush" in East Kalimantan, Indonesia [Internet]. Chiang Mai: Brics Initiative for Critical Agrarian Studies (BIGAS); 2015. Available from: www.plaas.org.za/bicas\%5Cnwww.iss.n 1/bicas\%5Cnhttp://rcsd.soc.cmu.ac.th

6. Ivers L, Cullen K. Food Insecurity: Special Considerations for Women. Am J Clin Nutr. 2011 Nov 16;94:1740S-1744S.

7. Aprodev. No Security Without Food Security No Food Security Without Gender Equality. Report Of Good Conference 18-20 September 2002. Committee on World Food Security; 2003.

8. World Rainforest Movement. Impacts of public health nutrition program to address food insecurity in rural areas. Future studies will require more adequate research designs and larger sample sizes to determine the correlation between the nutritional status of women and food insecurity.

oil palm plantations on biodiversity. Cameroon; 2019.

9. FAO/ WHO. NATIONAL NUTRITION STRATEGY International Conference on Nutrition. 2nd Int Conf Nutr [Internet]. 2013;1-52. Available from: http://www.fao.org/3/a-at618e.pdf

10. Lemeshow S, Hosmer DW, Klar J, Lwanga SK. Lemeshow. Adequacy o. Kusnanto H, editor. Yogjakarta: Gadjah Mada University Press; 1997.

11. Frongillo EA, Rauschenbach BS, Olson CM, Kendall A, Colmenares AG. Questionnaire-Based Measures Are Valid for the Identification of Rural Households with Hunger and Food Insecurity. J Nutr. 1997;127(5):699_ 705.

12. Studdert LJ, Frongillo EA, Valois P. Household Food Insecurity Was Prevalent in Java during Indonesia's Economic Crisis. J Nutr. 2001;131(10):2685-91.

13. Noviani, Nor Eka; Kandarina, Istiti; Nisa' FZ. Ketahanan Pangan Rumah Tangga dan Akses Pangan sebagai Faktor Risiko terjadinya Diabetes Melitus Tipe 2. J Mitra Kesehat. 2018;1(2):117-24.

14. Sirajuddin, Surmita, Astuti T. Food Consumption Survey. Suhardianto A, Saputri NL, Sapriyadi, editors. jakarta: Kementerian Kesehatan Republik Indonesia; 2018.

15. Kemenkes RI. Tabel Batas Ambang indeks Massa tubuh (IMT) [Internet]. P2PTM Kemenkes RI. 2019 [cited 2019 Dec 18]. Available from: http://p2ptm.kemkes.go.id/infographic-p $2 \mathrm{ptm} /$ obesitas/tabel-batas-ambang-indek s-massa-tubuh-imt

16. Supariasa ID., Bakri B, Fajar I. 
Nutritional Status Assessment. Buku Kedokteran EGC. Jakarta: Buku Kedokteran EGC; 2013.

17. Mohd Shariff Z, Tham B. Food security and child nutritional status among Orang Asli (Temuan) households in Hulu Langat, Selangor. Med J Malaysia. 2002 Mar 1;57:36-50.

18. Sharmin S, Hamid N, Muda W. Prevalence and Associated Factors of Food Insecurity among Women Garment Factory Workers in Bangladesh. Int J Food Microbiol. 2019 Mar 7;

19. Quisumbing A, Maluccio J. Resources at Marriage and Intrahousehold Allocation: Evidence From Bangladesh, Ethiopia, Indonesia, and South Africa. Oxf Bull Econ Stat. 2003 Feb 1;65:283327.

20. Naser I, Jalil R, Manan W, Wan Nik WS, Mohd Shariff Z, Abdullah M. Association between household food insecurity and nutritional outcomes among children in Northeastern of Peninsular Malaysia. Nutr Res Pract. 2014 Jun 11;8.

21. Mahmudiono $T$, Nindya $T$, Andrias $D$, Megatsari H, Rosenkranz R. Household Food Insecurity as a Predictor of Stunted Children and Overweight/Obese Mothers (SCOWT) in Urban Indonesia. Nutrients. 2018 Apr 26;10:535.

22. Belsky D, Moffitt T, Arseneault L, Melchior M, Caspi A. Context and Sequelae of Food Insecurity in Children's Development. Am J Epidemiol. 2010 Oct 1;172:809-18.

23. Chinnakali P, Upadhyay R, Shokeen D, Singh K, Kaur M, Singh A, et al. Prevalence of Household-level Food Insecurity and Its Determinants in an Urban Resettlement Colony in North India. J Heal Popul Nutr. 2014 Jun 1;32:227-36.

24. Bray J. Consumer Behaviour Theory: Approaches and Models [Internet]. 2008 [cited 2019 Nov 20]. p. 37-41. Available from: http://eprints.bournemouth.ac.uk/10107/

25. Mohamadpour M, Sharif Z, Keysami M.
Food Insecurity, Health and Nutritional Status among Sample of Palm-plantation Households in Malaysia. J Health Popul Nutr. 2012 Sep 1;30:291-302.

26. Yunieswati W, Marliyati SA, Setiawan B. relationship between nutritional status, health status, food consumption , and lifestyle to work productivity of cocoa. in: Proceeding of the 4th International Conference on Public Health. 2018. p. 33-9.

27. Velásquez-Meléndez G, Schlussel $M$, Brito A, Silva AA, Lopes Filho J, Kac G. Mild but Not Light or Severe Food Insecurity Is Associated with Obesity among Brazilian Women. J Nutr. 2011 Mar 1;141:898-902.

28. Farrell P, Thow AM, Abimbola S, Faruqui N, Negin J. How food insecurity could lead to obesity in LMICs: When not enough is too much: a realist review of how food insecurity could lead to obesity in low- and middle-income countries. Health Promot Int. 2017 May $24 ; 33$.

29. Leroy JL, Ruel M, Frongillo EA, Harris J, Ballard TJ. Measuring the food access dimension of food security: A critical review and mapping of indicators. Food Nutr Bull. 2015;36(2):167-95.

30. Park J, Lee JS, Jang YA, Chung HR, Kim J. A comparison of food and nutrient intake between instant noodle consumers and non-instant noodle consumers in Korean adults. Nutr Res Pract. 2011;5(5):443-9.

31. Ruanpeng D, Thongprayoon C, Cheungpasitporn W, Harindhanavudhi T. Sugar and artificially sweetened beverages linked to obesity: A systematic review and meta-analysis. Qjm. 2017;110(8):513-20.

32. Kant AK. Consumption of energy-dense, nutrient-poor foods by adult Americans: nutritional and health implications. The third National Health and Nutrition Examination Survey, 1988-1994. Am J Clin Nutr [Internet]. 2000 Oct 1;72(4):929-36. Available from:https://doi.org/10.1093/ajcn/72.4.9 29 